\title{
The humble sardine (small pelagics): fish as food or fodder
}

\author{
Moenieba Isaacs ${ }^{*}$ (1)
}

\begin{abstract}
Background: The group of small pelagic fish is the largest species group landed globally. A significant proportion of this nutrient-rich food is processed and lost to livestock feed, fish feed, fish oil, pet food and omega-rich vitamins. The nutritional importance of small pelagics as an easily digestible protein source, rich in essential lipids with fatty acids (EPA/DHA), essential amino acids, minerals and vitamins, is well known and documented. Small pelagics contain all the elements of a healthy and nutritionally optimal food source for humans and are an important contributor to the food and nutritional security of many poor, low-income households in developing countries.
\end{abstract}

Findings: Large-scale and small-scale fisheries play an important role in contributing to food security and nutrition. Yet, all of the anchovy landings from large-scale fisheries are reduced to animal feed, fish oil and pet food in South Africa. The size of the species, labour costs and lack of incentives by the state are some of the challenges to redirecting anchovy for human consumption. This trend is also now prevalent in Tanzania, where most (84\%) of the dagaa fished is reduced to fishmeal in Kenya, mainly to feed chickens. The main challenges are post-harvest handling and sanitation.

Conclusions: The redirecting of small pelagics to human consumption will depend on the role of the state in Tanzania and South Africa in investing in post-harvest processing. The role small-scale fisheries play in providing fish for food security needs to be understood in the context of economic viability and of how data are reported in this sector as compared to large-scale fisheries.

Keywords: South Africa, Tanzania, Food security, Nutrition, Consumption, Small-scale, Large-scale, Small pelagics

\section{Background}

Long-term food insecurity leads to undernourishment, in which the body receives insufficient nutrients, either macro- or micronutrients. Protein is an example of a macronutrient, and amino acids, vitamins and minerals are examples of micronutrients. Undernourishment has been studied extensively in underweight children stunted by growth and wasted around the waist. In an attempt to stress the importance of nutrition, pregnant women and breastfeeding mothers are also important focus groups being studied extensively. In 2013, UNICEF reported the alarming malnutrition statistic that over one-third of all stunted (low height for age, caused by long-term

\footnotetext{
*Correspondence: misaacs@uwc.ac.za

Institute for Poverty, Land and Agrarian Studies (PLAAS), University of the Western Cape (UWC), Cape Town, South Africa
}

insufficient nutrient intake) children and one-third of all wasted (low weight for height, a strong predictor of mortality among children under five) children lived in Africa [1]. About one-third of all deaths among under5 -year children in Africa are caused by malnutrition. In addition, food and nutrition security is still one of the major constraints facing child survival in many African countries today. Furthermore, micronutrient deficiency is a major problem worldwide, as two billion people are reported to be deficient in the micronutrients crucial for human development [2, 3]. In many countries in Africa, diet consists predominantly of starch, while fish is fairly readily available in many riparian and coastal communities and could play an important role in enriching diets deficient in vitamins and minerals.

Fish as food does not represent a significant percentage of the calorie intake for many poor people, although it is 
a healthy and affordable food source, rich in high-quality protein and essential micronutrients and vitamins. Adding fish to the rice, maize, bread and noodles, etc., consumed by many poor, would contribute significantly to providing vitally needed nutrients.

\section{International recognition of fish as nutrient source}

The International Conference on Sustainable Contribution of Fisheries to Food Supply held in Kyoto, Japan, in 1995 identified fish (marine, inland or aquaculture) as playing a significant role in food security. Delegate states approved a Declaration and Action Plan to enhance the contribution of fisheries to human food supply $[4,5]$.

To address the right to food for many poor and malnourished people, there is an increased emphasis in international organisations (Committee on Food Security, Food and Agriculture Organisation and many donor countries) on the importance of the nutritional contribution of fish as food to be considered in the diet of the poor. International instruments and commitments, such as the Voluntary Guidelines on Responsible Governance of Tenure of Land, Fisheries and Forests in the context of National Food Security (Tenure Guidelines) [6] and the Voluntary Guidelines on the Progressive Realization of the Right to Adequate Food in the Context of National Food Security (Right to Food Guidelines) [7], endorse the important role of small-scale fisheries in contributing to food security. More specifically, the UN's Special Rapporteur on the Right to Food makes "the explicit link between right to food and rights of those who produce it, to fair access to resources such as fish and water" [8].

\section{International recognition of small fisheries}

The often ignored, underestimated, undervalued and overlooked small-scale fisheries finally gained traction when the Voluntary Guidelines for Securing Sustainable Small-Scale Fisheries in the Context of Food Security and Poverty (Small-Scale Fisheries Guidelines) [9] by the Committee on Fisheries of the Food and Agriculture Organization of the United Nations (FAO) was adopted in 2014. The Committee on Food Security (CFS/FAO) Higher Level Panel of Experts (HLPE) [3] report on Sustainable Fisheries and Aquaculture for Food Security and Nutrition reconfirmed the importance of small-scale fisheries in contributing to food security and nutrition.

Internationally the debates on fish as food, livelihood, income, trade, feed and forage have all been gaining traction internationally with specific reference to small-scale fisheries and the right to food campaigns by civil society. The nutritional importance of small pelagics, which include sardines, mackerels, anchovies, etc., is widely known, and many small-scale fishing communities consume the small fish. Since fish is one of the most traded commodities in the world, the nutritional importance of protein and micronutrients in developing countries is often compromised for sale on the local, regional and international markets. Feeding into the debate fish as a livelihood and income to provide indirect food security, the findings of the FAO/NORAD report in 2013 indicated that local fishers rarely benefit from "fish for whom" debates concerning the international demand for small pelagics competing with the fish as food [10].

\section{Current predominant use of small pelagics worldwide}

More small pelagic fish are landed globally than any other type of fish. ("Landed" refers to the portion of the catch retained and not discarded at sea.) Large-scale trawling for pelagic species, with notable exceptions, is most often linked to supplying fish feed for industrial aquaculture [11]. Forage species, into which small pelagic fish fall, are among the most populous in the world, and demand for products derived from forage fish is increasing. Some would argue that forage species are at the heart of the human food system.

Small pelagics are used to fuel the growing global demand for animal protein as global incomes rise and diets change. Large-scale industries process forage fish using what is called "reduction", which involves cooking, grinding and chemically separating the fat from its protein and micronutrients. The fat and protein form key ingredients in the chemical inputs into animal feed for aquaculture, industrial livestock, chicken farming, a growing pet food sector and bait. The micronutrients such as nitrogen, phosphorus and potassium are converted into crop and vegetable fertiliser. This oil- and protein-rich meal becomes animal feed. The fats are used to make human nutritional supplements such as fish oil and omega-3 fatty acid tablets. Small pelagics are as important for human consumption as they are for the ecosystem, and the balance is important [12-16].

\section{Defining small pelagics}

Small pelagics are small forage fish that live in the surface and near-surface waters over the continental shelf of most of the coast. Forage fish are small schooling fish that feed on plankton and occupy a vital place in marine foodwebs. Generally, these species eat herbivorous (phytoplankton) or carnivorous (zooplankton) plankton and are eaten by larger predators that occur higher up in the foodweb. Forage fish therefore play a fundamental role in marine ecosystems by converting energy from lower trophic levels into food for larger fish, marine mammals and seabirds-essentially all predators at higher trophic levels in the marine environment [17]. This paper focuses on small pelagic species in two case study sites in South Africa (marine-ocean fisheries) and Tanzania (inlandfreshwater lake fisheries). 


\section{The South African west coast small pelagic fisheries}

The South African, small pelagics (anchovy Engraulis encrasicolus and sardine Sardinops sagax), together with associated bycatch for red-eye round herring (Eriumeus whiteheadii) and cape horse mackerel (Trachurus trachurus), form a capital-intensive industrial fishery based on the west coast of South Africa in the southern Benguela region (Fig. 1). Most of the small pelagic fishery infrastructure (the fishing fleet and major canning and fishmeal factories) is situated on the west coast in the greater Saldanha Bay, St Helena Bay and Velddrif areas. Since the 1940s, canning and fishmeal have been part of this sector's operations, and 6 canning and processing companies and 15 packing entities have been operational. Coastal communities have settled in and around this area, largely based on employment derived from the fishing industry $[17,18]$.

Sardine catches have dominated to the extent that $60-90 \%$ of the pelagic industry in South Africa consisted of pilchard (sardine) and anchovy (see Fig. 2). The ratio between pilchard and anchovy landings has, however, fluctuated over the decades. Two collapses of the sardine fishery have been reported: in the early 1960s and 1997 due to intensive overfishing and in the early 2000s due to the regime shift of sardine to the southern Benguela coast $[21,22]$. The significant shifts in winds in the El Niño years of 1983 and 1997 resulted in increased upwelling variability, causing a sudden upsurge in abundance of small pelagic in the southern Benguela. Views on what caused these environmental changes are contested, but El Niño, climate change, global warming and overfishing were frequently mentioned as factors that impacted on the productivity of the small pelagic resources, fishing possibilities and the distribution of the resource [23].

\section{Governance of South African small pelagic fisheries}

South Africa's fisheries are a right-based system of allocating Individual Transferable Quotas based on scientific inputs through Operational Management Procedures (OMPs) that sets annual TAC for anchovy and sardines. The Ecosystem Approach to Fisheries has governed the fisheries since $2002[19,20]$ supported by a consultative and advisory form of comanagement via the Scientific Working Group and Resource Management Working Groups, on which fisheries department scientists, University scientists, government officials, NGOs (WWF and industry associations) are represented.

\section{The Lake Victoria small pelagic fisheries}

Lake Victoria is the largest fresh water body in Africa, and Kenya, Uganda and Tanzania share the management responsibilities (see Fig. 3). Commercially important species are Nile perch, dagaa and tilapia. The Nile perch and Nile tilapia were introduced to Lake Victoria in the 1950s and experienced explosive population growth in the 1970s, while negatively impacting the 300 indigenous species almost to extinction. This study specifically focuses on the small pelagic dagaa silver cyprinid (Rastrineobola agrentea), a species in the family of Cyprinidae, found in Lake Victoria [24]. The silver cyprinid is known by various local names such as dagaa in Tanzania, mukene in Uganda and omena in Kenya.

This fishery is a labour intensive, artisanal and small scale in nature using traditional methods of fishing in dug-out canoes, purse-seine and bright lanterns as fishing activity mainly takes place at night. When the fish is landed, it is sold to women who spread it out in the sun to dry for a period of 2 days. Drying is often done on sand, rocks and nets and some instances on drying racks $[24,25]$.

The Dagaa stocks have steadily increased, along with the catches, since the mid-1980s (see Fig. 4). Since 2005 it has become the largest fishery in the lake by weight and there are no signs of overexploitation. As the stock size, based on hydroacoustic surveys, still appears to be increasing, this would indicate that there is still room for expansion of this fishery [26].

\section{Governance of dagaa fisheries on Lake Victoria}

The dagaa fishery is situated in traditional communal tenure systems that link the management of land, lake (water) and fish species. An open-access fisheries management system is still prevalent on Lake Victoria for the dagaa fisheries, with a comanagement system established with the creation of Beach Management Units (BMUs). The role of the BMU is mainly self-policing, but it is not actually part of the decision-making structures. Onyango 2011 [27] labels the comanagement introduced by the World Bank as a top-down system that lacks legitimacy and compliance at local level around the lake. More or less at the same time a regional management institution, known as the Lake Victoria Fisheries Organisation (LVFO), was established, and all states (Kenya, Tanzania and Uganda) that share the resource formed part of this structure to manage and develop the utilisation of the fisheries, as well as to coordinate research and management regulations $[26,27]$.

\section{Methods}

The methodology for this paper is gleaned from literature review and fieldwork in Tanzania and South Africa on unpacking the contribution of small pelagics to fish as food or income. Data collection in South Africa for this paper is gleaned from key informant interviews and interviews with workers, unions and industry associations between 2012 and 2015. In Tanzania interviews 


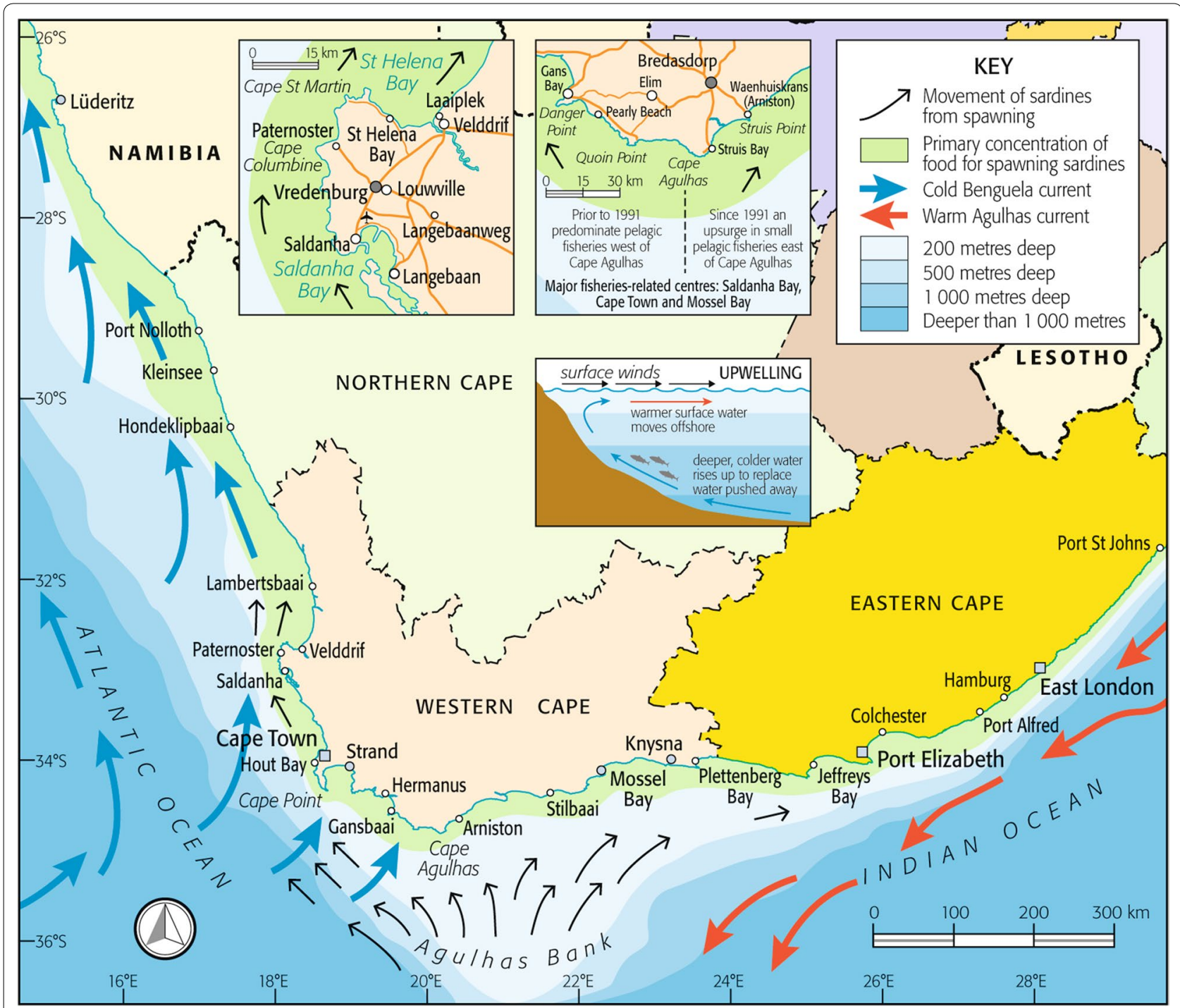

Fig. 1 Map of location, spawning grounds of Agulhas Bank, surface winds upwelling, spatial shifts

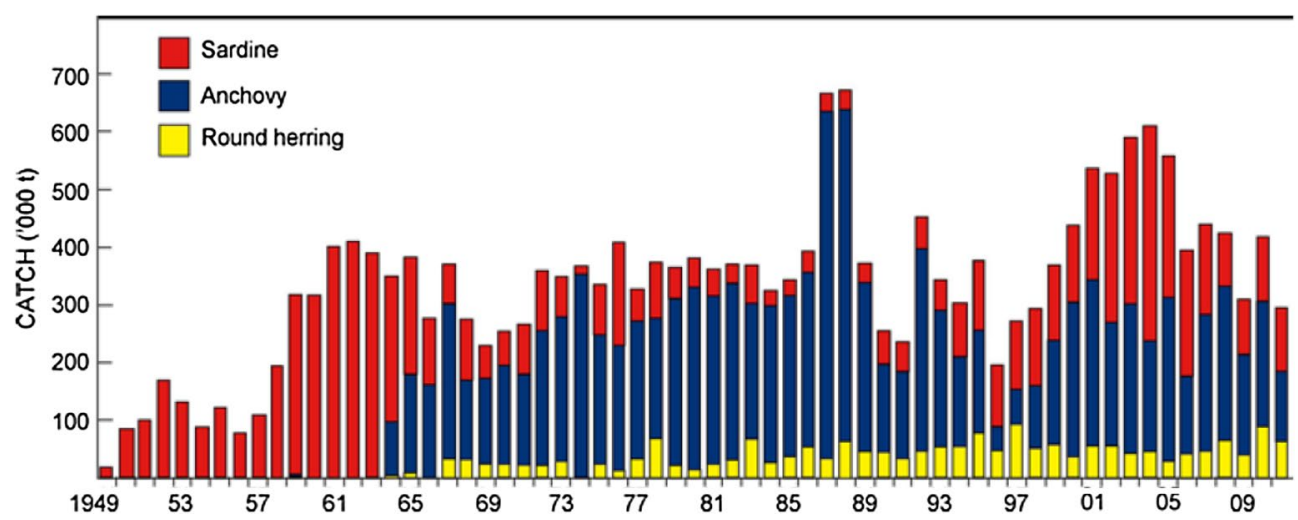

Fig. 2 Annual catches of sardine, anchovy and round herring taken by South African pelagics fishery from 1949 to 2011 [58: 46] 


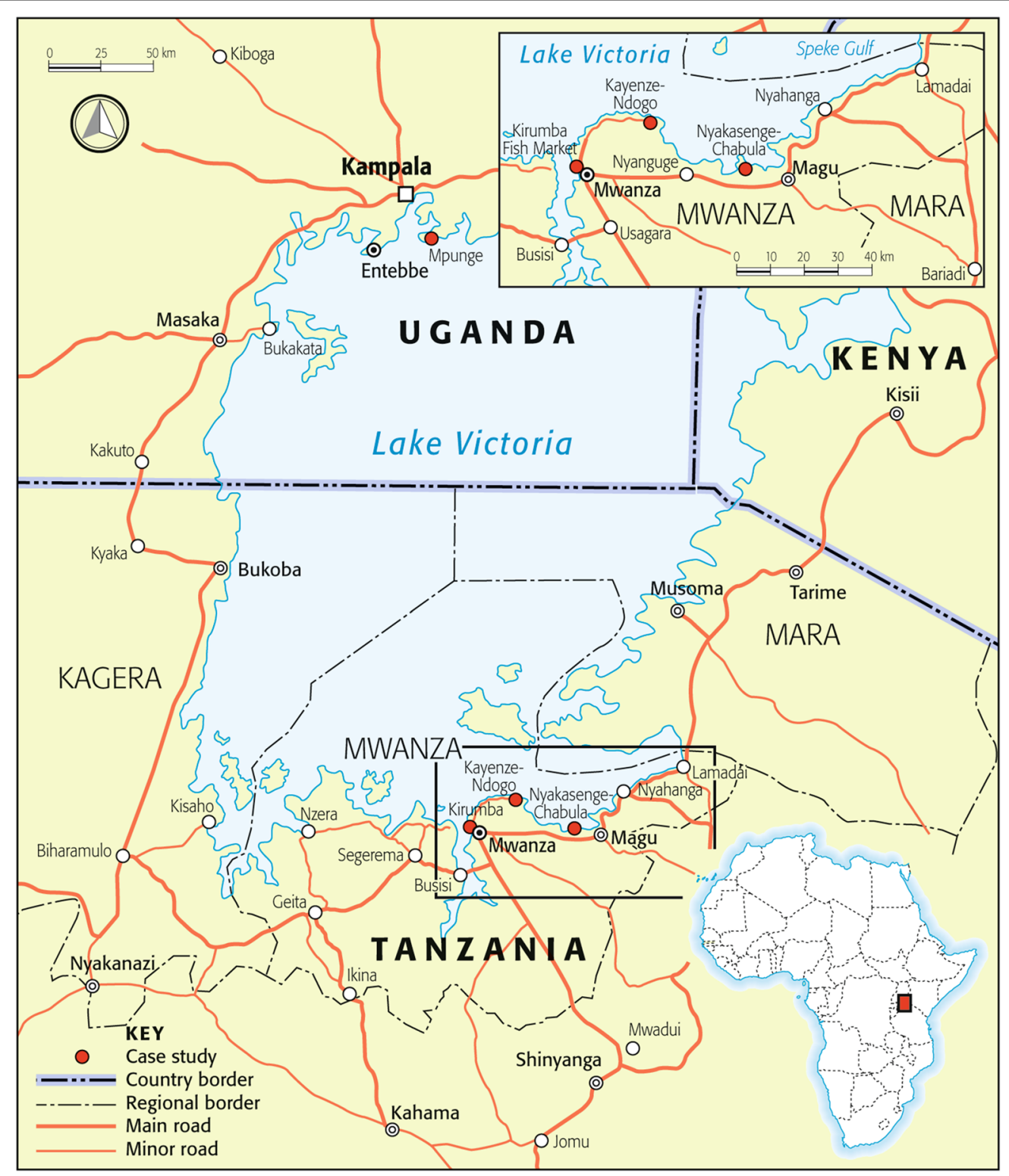

Fig. 3 Map of Lake Victoria, field sites in the Magu district, Mwanza Tanzania

were conducted with Beach Village Committee members, fisheries officials, cooperatives in the fish markets and fisheries researchers in the Magu district of Kayenze Ndogo, Nyakasenge Chabula, Kayenze and Kirumba fish market in October 2015 (Fig. 3).

The frame of analysis for this paper is mainly gleaned from the social and economic indicators originally developed by Thomson in 1980 (see Fig. 5) to show how national and international fisheries policies tend to favour the large-scale sector through fuel subsidies and investments, while small-scale fisheries remain undervalued, data on them are often not reported, and they are often ignored in their contribution to food and nutrition security [28].
The key indicators for this paper aim to examine the extent to which large- versus small-scale small pelagics contribute to food security and nutrition, and are landed value, human consumption, employment, discards and fishmeal reduction. The main argument for this paper is based on the following key questions: What is the nutritional importance of small pelagics especially to the poor and vulnerable in the developing countries? To what extent are small and large-scale fisheries contributing to food security and nutrition? What percentage of small pelagics (marine and inland) is reduced to animal feed, aquaculture feed, fish oil, etc., in South Africa and Tanzania, and what percentage is directed for human consumption? 


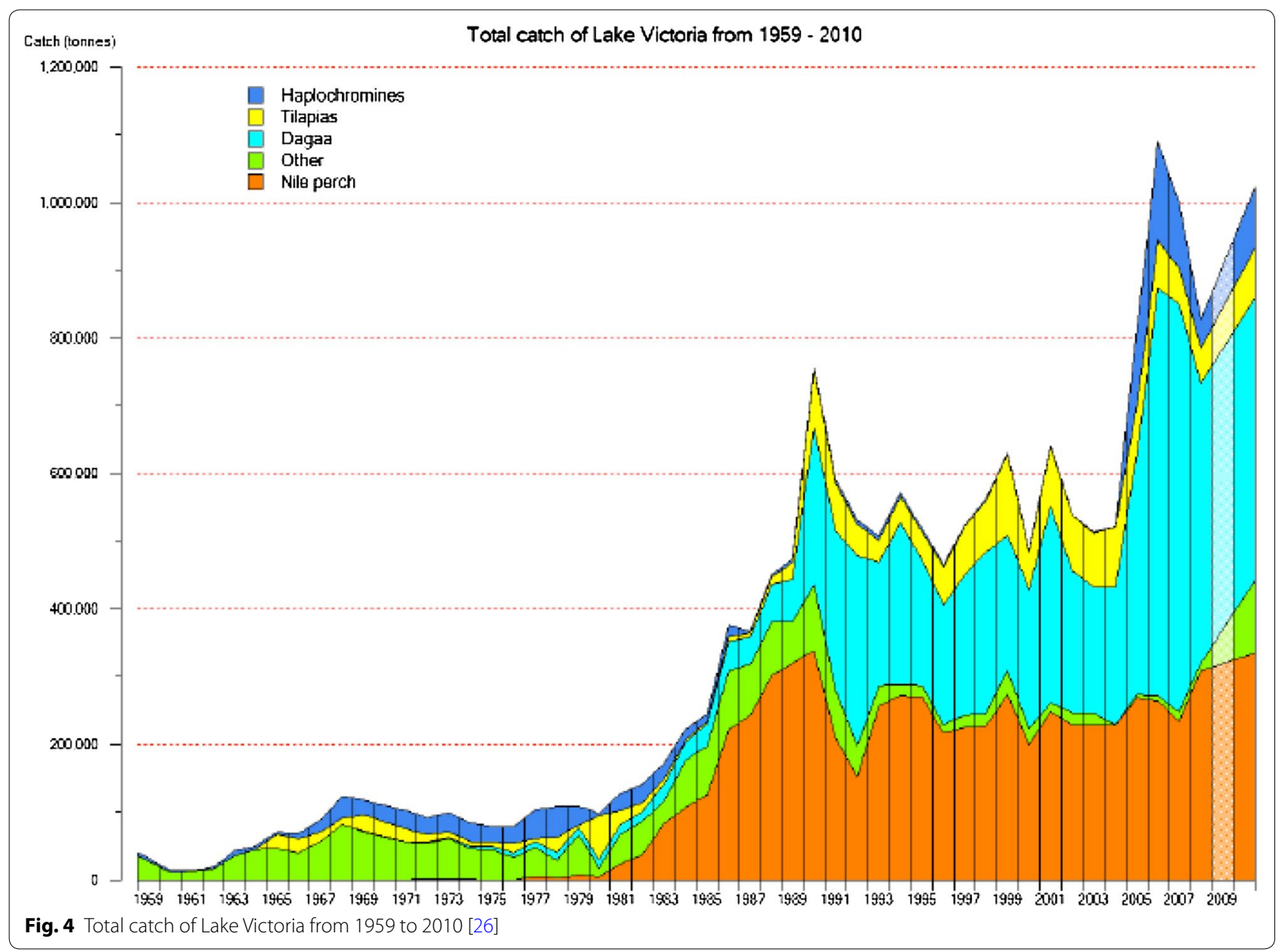

\section{Contextualising food and nutrition security Situating food security in context of the food system}

The notions of food security and the nutritional needs of the poor need to be understood within the food system; therefore, access to food includes the availability, affordability and consumption practices of food. Linking food security to the food system needs to address the issue of what the economic, social and environmental drivers are that affect the food security of the poor [29]. At the centre of these concerns is the demand for high-quality fish at low prices [30], and a better understanding of consumption and purchasing practices among the global rich [31]. How does the demand for high-quality fish impact on the livelihoods and income of many small-scale fisheries around the world? As one of the most traded commodities in the world, the trade of fish is integrated into national economies and to the global economy through trade and investment rules and privatisation and is supported by technological advances. On the other hand, localisation is a process that reverses the trend of globalisation by discriminating in favour of the local $[32,33]$.
Researchers [3, 10, 34-37] warn us that the food quality standards imposed by international trade institutions and importing countries are excluding small-scale fishers from benefitting from the high-value fish trade. Hence, the many small-scale fisher organisations are promoting direct local trade instead of international trade.

Malnutrition can be defined as chronic food consumption deficiencies, or the excess consumption of nutritionally poor food, or the consumption of mainly industrialised, processed food, or an abnormal physiological condition caused by deficiencies, excesses or imbalances in energy, protein and/or other nutrients [2: 4]. Malnutrition can include being under- or overweight, due to the correct nutrients not being consumed [39]. Malnutrition is not only caused as a result of a shortage of food, but is a result of a lack of nutritionally adequate food [38]. South Africa, a middle-income country, faces this "double burden" of malnutrition: both undernourishment and obesity [40]. The double burden is related to South Africa's extreme levels of inequality and the country's large poor population and is exacerbated by rapid change 


\begin{tabular}{|c|c|c|}
\hline Advantage & $\begin{array}{l}\text { Large scale } \\
\text { company } \\
\text { owned }\end{array}$ & $\begin{array}{l}\text { Small scale } \\
\text { artisanal }\end{array}$ \\
\hline $\begin{array}{l}\text { Number of fishermen } \\
\text { employed }\end{array}$ & Around 2 million & 0 million \\
\hline $\begin{array}{l}\text { Marine fish caught for } \\
\text { human consumption }\end{array}$ & Around 40 million tonnes annually & Around 40 million tonnes annually \\
\hline $\begin{array}{l}\text { Capital cost of each } \\
\text { job on fishing vessel }\end{array}$ & 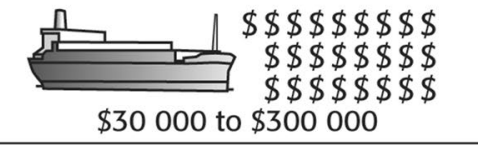 & $\underbrace{}_{\$ 100} \$$ \\
\hline $\begin{array}{l}\text { Bycatch discarded } \\
\text { at sea }\end{array}$ & Around 5 million tonnes annually & Around 2 million tonnes annually \\
\hline $\begin{array}{l}\text { Marine fish caught for } \\
\text { industrial reduction } \\
\text { to meat and oil, etc. }\end{array}$ & $\begin{array}{l}\text { Around } 15 \text { million } \\
\text { tonnes annually }\end{array}$ & Almost none \\
\hline Fuel oil consumption & $\begin{array}{l}\text { 90700 } \\
30 \text { to } 40 \text { million tonnes annually }\end{array}$ & 3 to 15 million tonnes annually \\
\hline $\begin{array}{l}\text { Fish landed per tonne } \\
\text { of fuel consumption }\end{array}$ & & 3 to 15 tonnes \\
\hline $\begin{array}{l}\text { Fishermen employed for } \\
\text { each } \$ 1 \text { million invested } \\
\text { in fishing vessels }\end{array}$ & 3 to 30 & 200 to 10000 \\
\hline
\end{tabular}

Fig. 5 Advantages for small-scale fisheries when comparing large-scale fisheries operations [updated from 3, 28, 53, 64]

in the South African food system. Many poor people are increasingly distanced from self-sufficiency as they abandon local dietary foods and increase their dependence on processed and industrialised foods [41]. Families eat the same very limited foods day in and day out. Highly processed starchy foods are prioritised for energy and take up substantial space on the plate. The animal proteins many families consume tend to be of very poor quality, for example, processed meat and chicken feet and heads with increased levels of salt and fat. "Women are carrying their poverty on their bodies" with the increased intake in starchy, sugary and processed cheap foods [42: 26].

\section{Value of small pelagics in nutrition}

Fish provides an excellent solution for food insecurity and malnutrition, especially small pelagics that are rich in macro- and micronutrients. Fish is a particularly good source of protein for children, which is vital for their growth, and their underdeveloped digestive systems often cannot process the more starchy staple foods [43]. Fish in the human diet makes a significant contribution to meeting health needs, as it provides protein that contains all essential amino acids, lipids with essential omega- 3 fatty acids and other vitamins and minerals [3]. It is crucial that fish protein of sustainably harvested species like small pelagics is directed towards human consumption [41]. Small pelagics provide easily digestible protein, and the bioavailability (the rate of absorption and availability of a substance to the human body) of the protein in fish is $5-15 \%$ higher than the protein from plant sources $[3$, $43,44]$. 
The nutritional benefits of small pelagic fish go beyond the importance of the role it plays as a source of protein. The lipid composition of fish is different from that of other proteins, and the long-chain, polyunsaturated fatty acids (LCPUFAs) have a number of potential health benefits [3]. The omega-3 docosahexaenoic (DHA) is also believed to be important during pregnancy, breastfeeding and infancy for neurodevelopment $[3,45]$. This omega-3 fatty acid, an important building block for neural and brain development in young children, is also found in various vegetable oils, but in these it is a form of fatty acid (alphalinolenic acid-ALA) that needs to be converted into DHA to be effective. The human body is, in fact, inefficient at converting the ALA into the necessary DHA. Therefore, fish is a far more reliable source of DHA. For brain development in children to be optimal, it is believed that an intake of only $150 \mathrm{mg}$ of small pelagic fish daily is necessary [3].

The omega- 3 oils found in fish have also been found to reduce unhealthy cholesterol and triglycerides (both of which are causes of heart disease) as well as increase healthy cholesterol [3, 46-49].

Fish is a source of lysine and methionine, which are essential micronutrients in the form of amino acids [3, 43]. Further micronutrients found in fish include Vitamins $\mathrm{A}, \mathrm{D}, \mathrm{B} 1$ and $\mathrm{B} 2$, as well as iron, phosphorous and calcium [3, 43]. Vitamin A is present in fish as retinol and an hydroretinol, which is more easily preserved through the cooking process and more readily absorbed by humans than the form of Vitamin A found in vegetables [50]. The calcium in fish, digested when the bones and organs are eaten, is even slightly more effective than milk as a source of calcium [50]. Fish is a rich source of iron and also aids the bioavailability of iron of other foods in a meal, such as rice [50]. The deaths of 800,000 children globally each year are attributed to zinc deficiency [3]. Small pelagic fish contain all of these micronutrients in significant amounts.

Over 30\% of people in the world are reported to be iron deficient, including up to $50 \%$ of pregnant women and children in developing countries, with approximately two billion being anaemic [3, 38]. Lack of iron impairs cognitive development, growth and immune function, very often resulting in suboptimal performance at school and in adulthood [38]. Fish added to the traditional blend of staple diets will increase the utilisation of micronutrients, indirectly boosting the immune system. Vulnerable populations such as young children, the aged and immunecompromised persons living with HIV and AIDS would benefit significantly from introducing small pelagics into their diet [5]. More importantly, fish as food is separated from the consumption of other foods produced on the land.

\section{Findings}

The consumption of fish contributes approximately $17 \%$ to the global intake of protein. In some countries in Africa, particularly West Africa, this can be significantly higher-up to $72 \%$ in Sierra Leone and $55 \%$ in Ghana and the Gambia [3]. The fish frequently consumed by local populations in Africa is the small pelagic fish, often regarded as a lower-value fish in terms of international trade.

\section{Difficulties of small pelagics for human consumption}

Small pelagics with their high fat content tend to spoil easily, which results in many post-harvest losses during handling, sanitation and drying. When small pelagics are placed directly on the soil, they become contaminated and become rancid, and placing fish on mats, concrete or drying racks improves the quality of the product [50]. In small pelagics, rancidity is caused by the oxidation of fish lipids, which leaves a bad odour and bitter taste. Smoking and salting small pelagics are not very popular in most parts of Africa. Salt is very expensive, and it changes the product, because, as with smoking, the species is easily charred [50] (blackened). Canning is one way of preserving the fish for human consumption, but is expensive, and canning is mostly confined to South Africa and Namibia.

\section{Advantages of small-scale fisheries in small pelagic fishing}

Large-scale pelagic trawls straddle temperate and tropical waters to harvest large shoals of small pelagic species within the Economic Exclusive Zones (extending 200 nautical miles of ocean space) many countries. Such operations are undertaken on a perennial basis. Along with the target pelagic species, significant numbers of larger-sized fish and marine mammals are also harvested, since the former are prey for the latter. Small-scale fishers would have caught these larger fish using more selective methods during the appropriate seasons. This again results in competition with local small-scale fishers, who are also often totally marginalised. In many quota-managed fisheries, these larger species are considered overexploited and hence denied to small-scale fishers, but the "incidental" catch by trawlers is often overlooked or condoned [43]. In these debates on fish as food, smallscale fisheries play the role of being more affordable, available and accessible to many poor populations and important to their livelihood [3]. The direct and indirect contribution to food security from small-scale fisheries outweighs the contribution of large-scale fisheries. The series of socio-economic indicators developed by Thomson in 1980 has been updated several times over the past 36 years $[28,51-55]$ to compare the contribution of large- versus small-scale fisheries, to address global estimates of employment, catches, bycatch and discards, 
human consumption and employment created through investments.

\section{Case studies}

The case of sardine and anchovy in South Africa

The economic boom for purse-seining started off along the underdeveloped west coast of South Africa in the late 1930 s and significantly increased with the post-Second World War demand for canned fish, technological advances and high unemployment rates [56]. This sector provided increased employment opportunities for many locals in the area [57]. From the 1950s to the 1980s, during the closed seasons between August and December, workers engaged in alternative livelihoods, i.e. fishing for west coast rock lobster and handline as a form of subsistence [57].

These fish are targeted by around 100 purse-seiners (dragnet fishing boats) that catch up to 400 tonnes a single haul. Anchovy and most of the round herring caught are reduced to fishmeal and fish oil in industries along the west coast. Sardines (also known as pilchards) are caught on the west and south coast of South Africa and canned or frozen locally for human consumption, pet food and bait. Established in the 1940s, the South African small pelagic industry, of which sardine is one of the main species fished, is the largest by landed volume and second only to demersal hake in terms of value [15, 58-60]. The employment in the sector is around 4500, but because operation is seasonal, it is difficult to differentiate employment that is permanent, temporary or seasonal.

The number of operational fishing vessels in the sector has declined by nearly one-third in the past decade, mainly as a result of most independent vessel owners leaving the industry. Also, factories have bought new and bigger boats following the assurance of being granted medium- and long-term rights. Further, owners have replaced old wooden vessels with larger, more fuel-efficient steel or fibreglass vessels with refrigeration systems. The maximum number of vessels allowed in the sector is about 100 [20]. The number of vessels operating at any given time is largely influenced by the annual quota size; for example, only 71 vessels were declared operational for the 2011 season, based on permits issued. The use of fewer, more efficient, mechanised vessels has resulted in job losses for skippers and crew [60]. Smaller operators off the Gansbaai coast have been pushed out by larger companies, because when there is an oversupply, large companies prioritise their own vessels over contracted vessels $[18,60]$. Increased competition for fish and crew employment to land an increased quantity and quality of catch has lead to the closing of fishing areas, high grading and dumping [60].

\section{Use of sardine in South Africa}

Canned sardine (pilchard) is one of the most important food items in the diets of South Africans, especially of the poor. The most common form is canned pilchards which come in mostly three recipes: in tomato sauce, in chilli sauce or in brine. Ease of storage and transportation and consistent quality count in the favour of canned sardines or pilchards. Another advantage is that canned sardines come in small tins of 155, 215 or $400 \mathrm{~g}$, all priced below one US dollar equivalent in South Africa. They can be eaten with bread, rice, potatoes, pap (maize meal) or even on their own. Canned pilchards can be found in all corners of South Africa, right into rural areas. The increasing expansion of South African retail chains into Africa is increasing the distribution and reach of food items such as canned sardines in the rest of Africa. Sardines are rich in micronutrients, vitamins and proteins (e.g. vitamins D and B12, protein and calcium). They are known to be one of the most concentrated sources of the omega-3 fatty acids, which lower triglycerides and cholesterol levels. There is no doubt therefore that sardine is vital for protein food security for the majority of South Africans, and increasingly Southern Africans, especially the poor [3]. It is no surprise that the sardine catches are caught at almost full capacity of the total allowable catch (TAC), see Fig. 6.

\section{Use and underuse of anchovy in South Africa}

Since the 1970s, South Africa's average annual anchovy landings have exceeded 300,000 tonnes. Some of the products produced earlier in South Africa were anchovy salted, dried or cured in oil, and anchovy paste. With the decrease in the average size of the anchovies (less than $12 \mathrm{~cm}$ ) in the 1980s, there was an increase in the manual labour required to prepare each fish individually, with a high risk of oxidation and rancidity, and the industry resorted to reducing far more anchovy for fishmeal [6163]. Figure 7 shows the annual catches of anchovy since 2006 , and for a number of years less than $50 \%$ of the TAC have been caught [61].

The undercatching of anchovy is a concern within the Department of Agriculture, Forestry and Fisheries in South Africa, as there is a need for food security and job creation in this sector. To mitigate this, in 2012-2013 Ukloba Fishing experimented with a new process of salting, curing and filleting anchovy for human consumption. The outcomes of this experiment were interesting, because filleting anchovy is labour intensive and therefore has job-creation potential. However, the company decided not to continue as the profitability would be low due to the labour costs [61]. In the end, mechanisation of the anchovy product for animal feed and fish oil seems to be the choice of many fishing companies in this sector. 

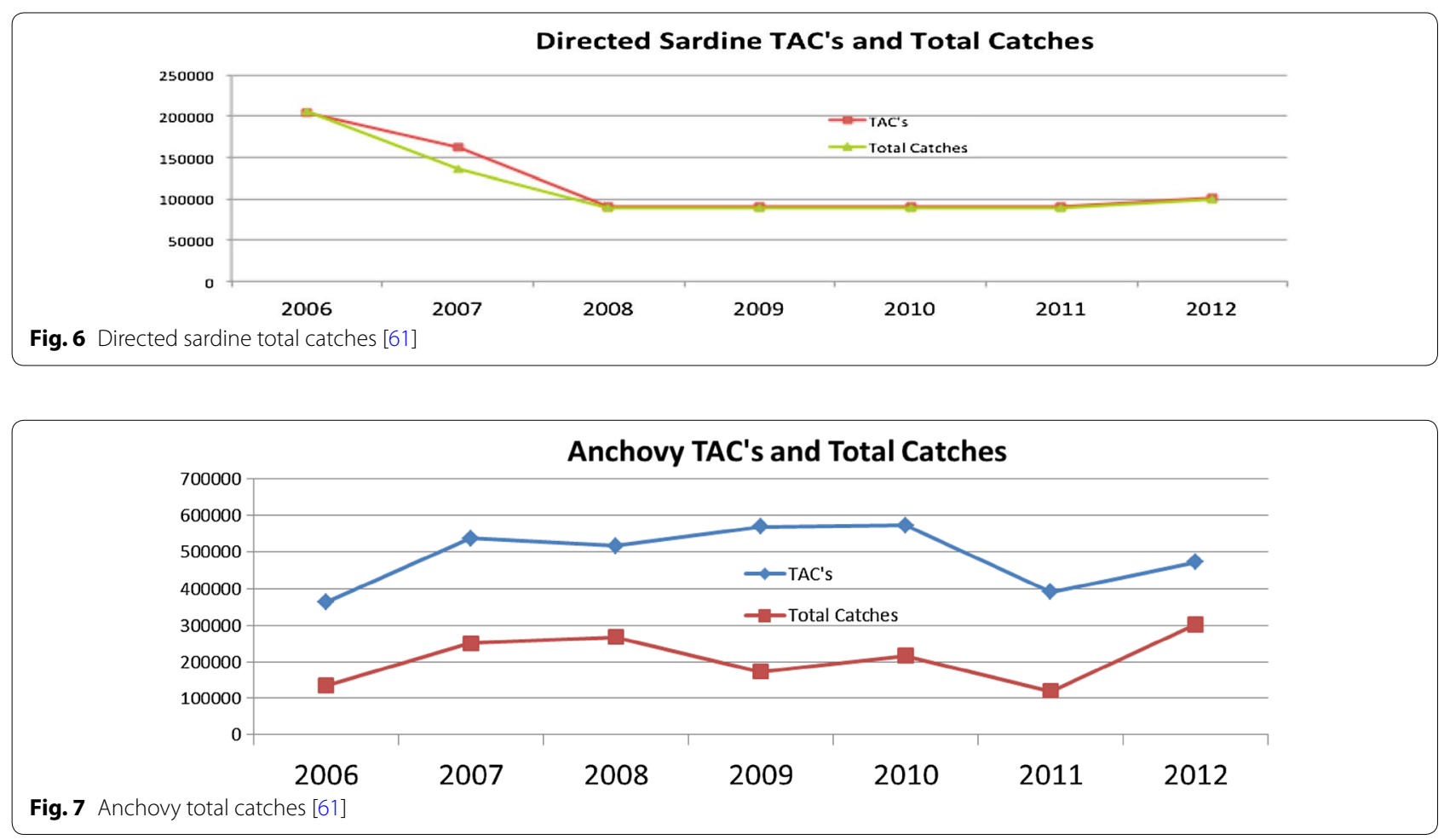

What is the role of small-scale fisheries in the product development of anchovy fillets for the higher end market [61-63]? Small-scale fishers do not target small pelagics due to the vessel size required and distance of the fishing from shore. When sardine shoals are swimming within the small-scale fishing zone, fishers will target them, but will use them for bait rather than consumption. Even small-scale fisher communities are far more likely to obtain their sardines from a tin than fresh.

\section{The case of the dagaa fisheries in Lake Victoria, Tanzania}

Lake Victoria is Africa's largest lake, covering an area of 68,800 square $\mathrm{km}$, and the lake is shared between Tanzania 51\%, Uganda $43 \%$ and Kenya $6 \%$. The maximum depth of the lake is $84 \mathrm{~m}$, and it has a shoreline of $3450 \mathrm{~km}$. The lake supports 30 million people living in the basin and is a major source of food, livelihoods and employment. Nile perch and Nile tilapia were introduced in the lake in the 1950s, which negatively impacted over 300 indigenous species to near extinction [64, 65].

\section{Dagaa fishing: methods and challenges}

The dagaa is a low-value species that is largely consumed around the lake and inland rural areas and animal feed (fishmeal). Trading dagaa on the global market is major challenge, as the post-harvest handling does not meet the minimum hygiene standards. Dagaa fishing is largely subsistence in nature due to the importance of fish consumption for many poor households around the lake, and in Eastern and Southern Africa, and has been a livelihood and income source for many small-scale fishers since the early 1970s [24]. The fish is caught at night with bright lanterns around the dug-out canoe by artisanal and small-scale fishers using traditional methods. When the fish is landed, it is sold to women who spread it out in the sun to dry for a period of 2 days. Drying is often done on sand, rocks and nets and some instances on drying racks.

\section{Loss of dagaa to human consumption}

The nature of the post-harvest handling of the fish, no cold chain (ice and refrigeration) and few drying racks mean that dagaa fishing does not meet the minimum hygiene standards to export globally. The Kirumba market sells mainly to local and regional markets, and currently most-almost $80 \%$ - of the dagaa sold at the Kirumba market in Mwanza is reduced for animal feed. The product is packed with sand and shells and for transportation in huge quantities to agents for the animal feed industries or to individual poultry farmers, mainly in the region, for example to Kenya, Burundi, Rwanda, Congo and within Tanzania [24]. There are new markets in the Far East such as Malaysia and Cambodia that import dagaa from Kirumba market [24, 25] in small quantities for their aquaculture production $[24,25]$. 


\section{Potential value of dagaa fishing}

In 2007, the estimated harvest level for the three riparian countries of Tanzania, Uganda and Kenya reached approximately 600,000 tonnes annually [65]. Since 2005, dagaa has become the largest fishing focus in the lake by weight, and there are no signs of overexploitation. Scientists and government officials agree that there is room for expansion in this arena of fishing [25, 26]. The development goals for the dagaa fisheries in Lake Victoria are to provide food security, employment and wealth creation. In line with these goals is the formalisation of the value chain to create more wealth and employment.

\section{Nutritional value of dagaa}

The nutritional value of dagaa is similar to that of marine small pelagic fish, in that they contain protein and micronutrients essential in the diet of growing children, pregnant and breastfeeding women and undernourished and malnourished communities. However, the handling and processing of the fish is key in ensuring the nutrition value is sustained [24].

\section{Discussion}

\section{Benefits of small-scale fisheries}

Globally, the landed value of large-scale fisheries is around 50 million tonnes annually, while for small-scale fisheries it is 40 million tonnes. About $8 \%$ of the catch is dumped before landing, and global discards are around 7 million tonnes annually [3]. Small-scale fisheries generate less wastage in the form of discards. There are many artisanal fishers, for example, in Mozambique that collect discards from large-scale vessels $[3,66]$. In the large-scale fisheries sector, huge quantities of small pelagic fish are reduced to fishmeal and fish oil. About 27 million tonnes of fish (34 per cent of the world fisheries catch) are processed into fishmeal, oil and pet food, etc., annually [2, $7,39,67]$. In the case study of South Africa, $100 \%$ of the anchovy and red-eye round herring are reduced to fishmeal, fish oil and pet food.

More of the small pelagic fish, even that reduced to fishmeal, could be used for human consumption. In Southeast Asia, specifically Thailand, most of the fishmeal is converted to products for human consumption. In the case of the dagaa fisheries, tonnes are reduced to fishmeal for chicken feed, and increasing amounts are exported to the new Far East markets for aquaculture production. This is of great concern as an important protein and micronutrients are reduced to protein for animal feed for foreign direct income, wealth creation and job creation, while millions of poor people around Lake Victoria are at risk from malnourishment.

Most of the fish-90-95\% [68]—caught by small-scale fisheries is destined for human consumption, while only
$80 \%$ of the large-scale fisheries' landings goes to human consumption [3]. Although large-scale fisheries produce four times the catch, the same amount in tonnes as for small-scale fisheries goes for human consumption. Mills et al. [68: 8] state that "an estimated 94\% (13 million tonnes) of small-scale inland production is consumed within the country of origin". Ultimately, both large-scale and small-scale fisheries make an important contribution to food security. The dagaa fish are consumed by the poor rural and urban people of the riparian states around the Lake Victoria, and they are clearly an important protein and micronutrient source to many. The sardine canning industry plays a significant role in providing nutritious meals to many urban and rural poor in South Africa. The trade of canned fish from South Africa also extends to Lesotho, Swaziland, Namibia, Zimbabwe and Malawi.

In terms of employment, however, over $90 \%$ of the fishers and fish workers are employed in small-scale fisheries. Employment in small-scale fisheries is several times higher per tonne than in large-scale fisheries [69]. An estimated 35 million commercial fishers are engaged in harvesting operations in the developing and developed countries [3].

Kurien's work on food security and trade makes the distinction between Bluefin tuna as fish for "luxury consumption" and anchovies as fish for "nutritional consumption" [43: 5]. The trade link to luxury consumption in Europe, Japan and the USA [43] results in the increase of income to small-scale fishers. In Tanzania, this rationale results in the high-value species Nile perch (fillet of white flesh fish) being exported to Europe and USA, while the bones and heads remain for locals to eat. This trend of increasing the amount of dagaa for animal feed will make the species more desirable for foreign income and compromise the protein and micronutrients available to the local poor. The food and nutrition needs of the poor in developing countries are often compromised by the need for income from trade and foreign investment, especially with the highervalue species [10]. The poor, who often harvest the fish, are not able to consume it. Protecting nutritionally important species for local consumption, rather than reducing it to animal feed, would be a first step in addressing the malnutrition of many vulnerable poor in Africa and especially Southern Africa. In addition, the small pelagics sector shows that the focus on efficiency, profit and the mechanisation of vessels and factories have failed dismally in creating employment, because these imperatives cause the shedding of jobs or zero growth in new jobs.

\section{Relook at what economic viability means for small-scale fisheries}

The next step is for a better understanding of the concept of economic viability for small-scale fisheries is in their contribution to food security and fish consumption. In 
analysing economic viability, Schuhbauer and Sumaila expanded the socio-economic indicators of the Thomson scale to include: the degree of economic dependence on fishing; the number of jobs per employment type; the fair distribution of benefits, subsidies, costs and cost structure and fish consumption; and governance indicators [55].

In Tanzania, the case of dagaa shows that the nutritional importance of the fish to food security is compromised by the safety and post-harvest handling of the fish, which causes almost $80 \%$ of the landed volume to be reduced to fishmeal. The sustainability of the resource is also threatened by the increasing use of motorised vessels and the decreasing use of dug-out canoes and sailboats. In South Africa, almost $100 \%$ of anchovy is reduced to animal meal. More investment in post-harvest handling, safety and improved hygienic standards, would allow a greater direction of dagaa towards human consumption. In South Africa, with the targeting of larger anchovy $(10-12 \mathrm{~cm})$, workers will need up-skilling in the process of de-heading and cleaning the anchovy for human consumption. This processing will be labour intensive, which brings opportunities for job creation. It will also bring new economic opportunities for product development in small-scale fisheries. At the same time, there is potential for addressing malnutrition [62].

Despite these opportunities for job creation and food security, it seems that the investment from the industry in further developing this sector is conditional upon government support and economic incentives. The small-scale sector could possibly benefit from product development and incentives from the state.

\section{Small-scale fisheries data-separate but equal}

Following on the need to define economic viability for small-scale fisheries, Pauly and Zeller reconstructed fisheries data and found many gaps in the data of the FAO especially when it comes to small-scale fisheries [70]. The data of small-scale fisheries and also subsistence fisheries are often not reported or are underestimated, ignored and rarely included in the national catch statistics [3]. This is especially important for small-scale fisheries and food security in particular inland fisheries and in rural household diets [3]. Pauly and Zeller call for a policy change that would be easy for "the FAO to coordinate and implement with all countries around the world [which] is to request countries to submit their annual catch statistics separately for large-scale and small-scale fisheries, which would be an excellent contribution towards the implementation of the Voluntary Guidelines for Securing Sustainable Small-scale Fisheries in the Context of Food Security and Poverty Eradication" [70: 5].

\section{Implementation and use of the soft laws}

The implementation and use of the soft laws (Tenure Guidelines, Right to Food Guidelines, Small-scale fisheries Guidelines $[6,7,9]$ ) should go further than only raising the profile and importance of small-scale fisheries rights to food and nutrition security, and protection of their livelihoods, by ensuring that these rights are protected in national policies and that the rights are realised. These rights and the livelihoods, lives, shelter and food of many small-scale fishers are also threatened and infringed on a daily basis by access to resources by coastal development, tourism, mining and large-scale acquisitions.

\section{Conclusion}

Small pelagic fish (marine and inland) play a critical role in the nutrition of many vulnerable and poor communities, especially in Africa. Mechanisation, overfishing and fishmeal production for cultured fish and animal feed all compromise the key position of small pelagics as food for the many malnourished and vulnerable coastal and inland populations.

The often ignored, undervalued, underestimated role and position of small-scale fisheries is gaining traction with support from the FAO voluntary guidelines (right to food, tenure and small-scale fisheries). Academics, conservation NGOs, donors and funders are all taking a keen interest in this sector. Space for action has been created for small-scale fishery civil society movements, both internationally and locally, to carefully align these soft law tools to the nature and structure of small-scale fisheries. This can be seen in the rights system, the management system (Territorial User Rights System) and the creation of marine protected areas in small-scale fishing zones. To fully realise the critical role small-scale fisheries play in food security and nutrition, they will need their governments' support in the development of these sector legislation investments.

Large-scale and small-scale fisheries play an important role in providing food security, as shown in the case of canning in South Africa and dagaa in Tanzania for human consumption. In cases like South Africa, where canning is providing high-quality protein, further investment is needed in the research and development of the role of small-scale fisheries in the use of the anchovy species for human consumption. Supporting investments in local markets and the local economy, and creating local value chains will be important in providing indirect food security through income and livelihood. The case of dagaa in Tanzania shows the need for post-harvest investments to increasing the quality of the fish for human consumption. The complex ecosystem and economic roles of small 


\section{pelagic fish necessitate a holistic view of their dynamics $[16,17,71]$.}

\section{Abbreviations}

ALA: alphalinolenic acid; CFS: Committee of Food Security; DAFF: Department of Agriculture, Forestry and Fisheries; DHA: docosahexaenoic; FAO: Food and Agricultural Organisation; HLPE: Higher Level Panel of Experts; LCPUFA: longchain polyunsaturated fatty acids; NGO: Non-Governmental Organisation; TAC: total allowable catch.

\section{Author information}

Moenieba Isaacs is an Associate Professor at the Institute for Poverty, Land and Agrarian Studies (PLAAS), University of Western Cape. Her research works extensively with fishing communities in South Africa to find policy solutions to the problem, which has highlighted the need to deal with social differentiation in fishing communities. She is an engaged scholar and curious on finding creative and appropriate ways to engage with social processes, decisionmaking and policymaking in the context of diverse civil society interests. Her research interests are on understanding the fish as part of the food system, the value chain, livelihoods of small-scale fishers in Southern Africa and internationally.

\section{Acknowledgements}

Dr. Paul Onyango is my research partner in Tanzania, and he was responsible for organising the fieldtrips and field interviews in Mwanza, Lake Victoria, Tanzania. This paper is part of the TBTI fish as food research cluster. Funding was provided by National Research Foundation (RSA) (Grant No. 86909).

\section{Competing interests}

The authors declare that he has no competing interests.

\section{Availability of supporting data}

The data for this paper were mainly sourced from secondary data as indicated in the list of references and lists of interviews data that are not in the format to share other than published material.

\section{Ethical approval and consent to participate}

This research was approved by the University of Western Cape and University of Dar res Salaam's Ethics Committees' and complied with informed consent, consent to participate, for all interviews and focus group interviews.

\section{Funding}

The author is grateful for the financial support of the National Research Foundation of South Africa and Commission of Science and Technology in Tanzania under the collaborative research agreement.

Received: 10 June 2016 Accepted: 27 October 2016

Published online: 25 November 2016

\section{References}

1. UNICEF. Improving child nutrition. The achievable imperative for global progress. United Nations Children's Fund. 2013. http://www.data.unicef. org/corecode/uploads/document6/uploaded_pdfs/corecode/NutritionReport_April2013_Final_29.pdf. Accessed 28 March 2016.

2. Allison E. Aquaculture, fisheries, poverty \& food security. Working paper 2011-65. Penang: The World Fish Center. 2011.

3. HLPE. Sustainable fisheries and aquaculture for food security and nutrition. A report by the High Level Panel of Experts on Food Security and Nutrition of the Committee on World Food Security. Food and Agriculture Organization of the United Nations. Rome: High Level Panel of Experts. 2014.

4. Thompson B, Amoroso L. Combating micronutrient deficiencies: food based approaches. Food and Agriculture Organization of the United Nations. 2011. ISBN-13: 9789251065464.

5. Scheiber HN, Paik J. Regions, institutions and law of the sea. Leiden: Martinus Nijhoff Publishers; 2013.
6. FAO. Voluntary Guidelines on the Responsible Governance of Tenure of Land, Fisheries and Forests in the context of National Food Security. Committee on World Food Security. Rome: Food and Agriculture Organization of the United Nations. 2012

7. FAO. Voluntary guidelines to support the progressive realization of the right to adequate food in the context of national food security. Rome: Food and Agriculture Organization of the United Nations; 2005.

8. De Schutter O. Note to the Secretary-General from the Special Rapporteur on the right to food. New York: United Nations, Sixty-seventh session General Assembly; 2012.

9. FAO. Voluntary guidelines for securing sustainable small-scale fisheries in the context of food security and poverty. Rome: Food and Agriculture Organization of the United Nations; 2014.

10. NORAD, FAO. A value-chain analysis of international fish trade and food security with an impact assessment of the small-scale sector: Summary report. Norwegian Agency for Development Cooperation and Food and Agriculture Organization of the United Nations. 2013.

11. Naylor R, Burke M. Aquaculture and ocean resources: raising tigers of the sea. Annu Rev Environ Resour. 2005;30:185-218.

12. Schleifer D. The fish at the heart of the food system. 2016: [Internet] 2016. http://limn.it/the-fish-at-the-heart-of-the-food-system/. Accessed 20 March 2016.

13. Tidwell J, Allan G. Fish as food: aquaculture's contribution. EMBO Rep. 2001;2(11):958-63. doi:10.1093/embo-reports/kve236.

14. Alder J, et al. Forage fish: from ecosystems to markets. Annu Rev Environ Resour. 2008;33:153-66. doi:10.1146/annurev.environ.33.020807.143204.

15. Tacon A, Metian M. Fishing for feed or fishing for food: increasing global competition for small pelagic forage fish. Ambio J Hum Environ. 2009·38(6):294-302 doi:10.1579/08-A-574.1.

16. Pikitch E, Boersma PD, Boyd IL, Conover DO, Cury P, et al. Little fish, big impact: managing a crucial link in ocean food webs. Washington, DC: Lenfest Ocean Program; 2012.

17. Coetzee J, Badenhorst A. Status and management of the South African small pelagic fishery_August 2013. Cape Town: Oceana Fishing Group: 2013.

18. Hara M, Rogerson J, de Goede J, Raakjær J. Fragmented participation in management of the fishery for small pelagic fish in South Africa-inclusion of small-rights holders is a complex matter. Afr J Marine Sci. 2014;. doi:10.2989/1814232X.2014.930708.

19. Shannon LJ, Cochrane KL, Moloney CL, Fréon P. Ecosystem approach to fisheries management in the southern Benguela: a workshop overview. Afr J Marine Sci. 2004;26(1):1-8. doi:10.2989/18142320409504046

20. RSA — Republic of South Africa. General Policy on the Allocation and Management of Long-term Commercial Rights: 2005. Pretoria: Minister of Environmental Affairs and Tourism.

21. Fairweather $T$, Hara M, van der Lingen C, Raakjær J, Shannon L, Louw G, Degnbol P, Crawford R. A knowledge base for management of the capital-intensive fishery for small pelagic fish off South Africa. Afr J Marine Sci. 2006;28(3-4):645-60.

22. Coetzee JC, van der Lingen CD, Hutchings L, Fairweather TP. Has the fishery contributed to a major shift in the distribution of South African sardine? ICES J Marine Sci. 2008;65:1676-88.

23. Isaacs M. Climate variability, overfishing and transformation in the small pelagics sector in South Africa. In: Guillotreau P, Bundy A, Perry I, editors. Global change in marine systems: societal and governing responses (forthcoming). Routledge Studies in Environment, Culture, and Society. Taylor Francis Group; 2017

24. Legros D, Luomba J. Dagaa value chain analysis and proposal for trade development. IOC-Smart fish programme technical document. 2011

25. Luomba J, Onyango P. Dagaa fishery, the unknown wealth of Lake Victoria. Visible possibilities: The economics of sustainable fisheries, aquaculture and seafood trade. In: International Institute of Fisheries Economics and Trade (IIFET) 2012 Tanzania Proceedings. Dar res Salaam, Tanzania. 2012.

26. Kolding J, Medard M, Mkumbo O, Zwieten PAM. Status, trends and management of the Lake Victoria Fisheries. In: Welcomme RL, ValboJørgensen J, Halls AS, editors. Inland fisheries evolution and management - case studies from four continents. FAO Fisheries and Aquaculture Technical Paper 579; 2014

27. Onyango P. Governance of tenure in the Lake Victoria fisheries, Tanzania. Land Land Tenure J. 2013; 1. 
28. Thomson D. Conflict within the fishing industry. ICLARM Newslett. 1980;1980(3):3-4.

29. Ericksen PJ. Conceptualising food systems for global environmental change research. Glob Environ Change. 2008;18(1):234-45. doi:10.1016/j. gloenvch.2007.09.002.

30. Freidberg SE. Culture, conventions and colonial constructs of rurality in south-north horticultural trades. J Rural Stud. 2003;19(1):97-109. doi:10.1016/S0743-0167(02)00037-2.

31. Kneafsey M, Dowler E, Lambie-Mumford H, Inman A, Collier R. Consumers and food security: Uncertain or empowered? J Rural Stud. 2013;29:10112. doi:10.1016/j.jurstud.2012.05.005.

32. Hines C. Localization: a global manifesto. London: Earthscan; 2000.

33. Hinrichs CC, Sterling VA. The practice and politics of food system localization. J Rural Stud. 2003;19(1):33-45. doi:10.1016/S07430167(02)00040-2.

34. Henson SJ, Brouder AM, Mitullah W. Food safety requirements and food exports from developing countries: the case of fish exports from Kenya to the European Union. Am J Agric Econ. 2000;82(5):1159-69.

35. Henson SJ, Mitullah, W. Kenyan exports of Nile Perch: impact of food safety standards on an export-oriented supply chain. World Bank Policy Research Working Paper, 3349. Washington, DC: World Bank. 2004

36. Mansfield B. Fish, factory trawlers, and imitation crab: the nature of quality in the seafood industry. J Rural Stud. 2003;19(1):9-21. doi:10.1016/ S0743-0167(2)00036-0.

37. Gibbon P, Ponte S. Trading down: Africa, value chains and the global economy. Philadelphia: Temple University Press; 2005.

38. Kambewa E, Ingenbleek P, Tilburg A. Improving income positions of primary producers in international marketing channels: the Lake Victoria-EU Nile Perch case. J Macromarketing. 2008;28(1):53-67. doi:10.1177/0276146707311305.

39. FAO. The right to food. United Nations General Assembly. New York: Food and Agriculture Organization of the United Nations; 2012.

40. Monteiro CA, Moura EC, Conde WL, Popkin BM. Socioeconomic status and obesity in adult populations of developing countries: a review. Bull World Health Organ. 2004;82(12):940-6. doi:10.1590/ S0042-96862004001200011.

41. Isaacs M. The governability of small-scale fisheries food system in South Africa-The case of snoek and West Coast rock lobster in Ocean View. In: Jentoft S, Cheunpagdee R, editors Interactive governance for small-scale fisheries: global reflections; 2005, p. 245-262. doi: 10.1007/978-3-319-17034-3_13.

42. PACSA. Food Price Barometer. Annual Report. Pietermaritzburg Agency for Community Social Action 2015.

43. Kurien J. Fish trade for the people: toward understanding the relationship between international fish trade and food security. Report of the Study on the impact of international trade in fishery products on food security. Food and Agriculture Organization of the United Nations and the Royal Norwegian Ministry of Foreign Affairs; 2004.

44. Bell J, Kronen M, Vunisea A, Nash W, Keeble G, Demmke A. Planning the use of fish for food security in the Pacific. Marine Policy. 2009;33(1):64-76. doi:10.1016/j.marpol.2008.04.002.

45. Mozaffarian D, Rimm EB. Fish intake, contaminants, and human health: evaluating the risks and the benefits. J Am Med Assoc. 2006;296(15):1885-99. doi:10.1001/jama.296.15.1885.

46. Seedat A. Know your fats and oils. The Heart and Stroke Foundation article. 2014. http://www.heartfoundation.co.za/topical-articles/ know-your-fats-and-oils.

47. Mozaffarian D, Lemaitre R, Kuller L, Burke G, Tracy R, Siscovick D. Cardiac benefits of fish consumption may depend on the type of fish meal consumed: the Cardiovascular Health Study. Circulation. 2003;107(10):13727. doi:10.1161/.CIR.0000055315.79177.16.

48. Sidhu K. Health benefits and potential risks related to consumption of fish or fish oil. Regul Toxicol Pharmacol. 2003;38(3):336-44. doi:10.1016/j. yrtph.2003.07.002.

49. FAO/World Bank/WorldFish Center. Small-scale capture fisheries: a global overview with emphasis on developing countries. A Preliminary Report of the Big Numbers Project. Food and Agriculture Organization of the United Nations, World Bank, WorldFish Centre 2008.

50. Thilsted $\mathrm{S}$, Roos N, Hassan N. The role of small indigenous fish species in food and nutrition security in Bangladesh. Naga ICLARM Q. 1997;20(3-4):13-5.
51. Kumulo-Johnson CA, Ndimele PE. A review of post-harvest losses in some African Countries. J Fish Aquatic Sci. 2011;6(4):365-78. doi:10.3923/ jfas2011365-378.

52. Berkes F, Mahon R, McConney P, Pollnac R, Pomeroy R. Managing smallscale fisheries. Alternative directions and methods. Ottawa: International Development Research Centre (IDRC); 2001.

53. Pauly D. Major trends in small-scale marine fisheries, with emphasis on developing countries, and some implications for the social sciences. MAST. 2006;4:7-22.

54. Kolding J, Béné C, Bavinck M. Small-scale fisheries-importance, vulnerability and deficient knowledge. In: Garcia S, Rice J, Charles A, editors. Governance for marine fisheries and biodiversity. London: Wiley; 2004. doi:10.1002/978118392607.ch22.

55. Schuhbauer A, Sumaila R. Economic viability and small-scale fisheries: a review. Ecol Econ. 2016;124:69-75. doi:10.1016/j.ecolecon.2016.01.018.

56. Crawford RJM. Food, fishing and seabirds in the Benguela upwelling system. J Ornithol. 2007;148(Suppl 2):S253-60. doi:10.1007/ s10336-007-0228-z.

57. Jarre A, Ragaller SM, Hutchings L. Long-term, ecosystem-scale changes in the southern Benguela marine pelagic social-ecological system: interaction of natural and human drivers. Ecol Soc. 2013;18(4):55. doi:10.5751/ ES-05917-180455.

58. DAFF. Status of the South African Marine Fishery Resources 2012. Republic of South Africa. Department Agriculture, Forestry and Fisheries. 2012.

59. DAFF. Status of the South African Marine Fishery Resources 2014. Republic of South Africa. Department of Agriculture, Forestry and Fisheries. 2014.

60. Hara M. Efficacy of rights-based management of small pelagic fish within an ecosystems approach to fisheries in South Africa. Afr J Marine Sci. 2013;35:315-22. doi:10.1080/03768350903181423.

61. De Goede J. Current fisheries management measures. Presentation at the anchovy for human consumption workshop, 12-13 March 2013 Marine Resources Management. Department of Agriculture, Forestry and Fisheries (DAFF). 2013.

62. Backteman K. Anchovy from fishmeal to fish for people. 2010.[Internet] 2016. http://www.efdinitiative.org/our-work/policy-interactions/anchovyfishmeal-food-people. Accessed 15 April 2016.

63. Japp D. Feasibility of Utilising South African Anchovy for Human Consumption. Capfish. Presentation at the Anchovy for Human Consumption Workshop, 12-13 March 2013.

64. World Bank and Food and Agriculture Organization of the United Nations. The Sunken Billions: the economic justification for fisheries reform. Washington DC: World Bank, Agriculture and Rural Development Department, Sustainable Development Network. 2009, p 130.

65. LVFO. Regional Status Report on Lake Victoria Bi-ennial Frame Surveys between 2000 and 2010. Kenya, Tanzania and Uganda. Supported by IFMP EDF Project Number 8 ACP/ROR/029 and GEF/LVEMP Phase II Project, Jinja, Uganda. Lake Victoria Fisheries Organisation. 2010.

66. Bene C, Macfadyen G, Allison E. Increasing the contribution of small-scale fisheries to poverty alleviation and food security. FAO fisheries technical paper 481. Rome: Food and Agriculture Organization of the United Nations. 2007.

67. Bostock J, McAndrew B, Richards R, Jauncey K, Telfer T, Lorenzen K, Little D, Ross L, Handisyde N, Gatward I, Corner R. Aquaculture: global status and trends. Philos Trans R Soc. 2010;365:2897-912. doi:10.1098/ rstb.2010.0170,

68. Mills DJ, Westlund L, De Graaf G, Willmann R, Kura Y, Kelleher K. Underreported and undervalued: small-scale fisheries in the developing world. In: Andrew NL, Pomeroy R, editors. Small-scale fisheries management: frameworks and approaches for the developing world. Wallingford: CABl; 2011.

69. Béné C, Hersoug B, Allison EH. "Not by rent alone": analysing the pro-poor functions of small-scale fisheries in developing countries. Dev Policy Rev. 2010;28:325-58. doi:10.1111/j.1467-7679.2010.00486.x.

70. Pauly D, Zeller D. Catch reconstructions reveal that global marine fisheries catches are higher than reported and declining. Nat Commun. 2016; doi:10.1038/ncomms10244.

71. Checkley DM, Alheit J, Oozeki Y, Roy C. Climate change and small pelagic fish. Cambridge: Cambridge University Press; 2009. 